\title{
REGULATION OF PEYOTE (LOPHOPHORA WILLIAMSII: CACTACEAE) IN THE U.S.A.: A HISTORICAL VICTORY OF RELIGION AND POLITICS OVER SCIENCE AND MEDICINE
}

\author{
Martin Terry \\ Sul Ross State University \\ Dept. Biology, Geology \& Physical Sciences \\ Alpine, Texas 79832, U.S.A. \\ mterry@sulross.edu
}

\author{
Keeper Trout \\ Cactus Conservation Institute \\ P.O. Box 12 \\ Boonville, California 95415, U.S.A.
}

ABSTRACT

\begin{abstract}
The peyote cactus, Lophophora williamsii, is presently classified as a Schedule 1 Controlled Substance in the USA, with an exemption for use as a sacrament in bona fide religious ceremonies of the Native American Church (NAC). Any botanist or other researcher seeking to work with peyote or any of its alkaloids, must comply with applicable (nontrivial) regulatory requirements. This paper presents an examination of the prohibition efforts that paved the way for current peyote regulation, accompanied by documentation of the religion-based political origins of such efforts, which involved the "acculturation" of Native Americans (i.e., the destruction of American Indian cultures). We also look at the historical emergence of a nationally organized and coordinated effort by missionaries and other prohibitionists to sell a federal anti-peyote law to Congress, which manifested itself repeatedly over a period of more than fifty years, before finally realizing success in the Controlled Substances Act of 1970. In view of ongoing changes in the legal/regulatory status of Cannabis sp. (another Schedule 1 plant that was targeted for illegality during the prohibitionists' rise to political predominance), we compare and contrast the two plants with speculation on peyote's future.
\end{abstract}

\section{RESUMEN}

El cactus peyote, Lophophora williamsii, actualmente se clasifica como una Sustancia Controlada en la Lista l en los EEUU, con una exención para su uso como sacramento en ceremonias religiosas auténticas de la Native American Church. Cualquier botánico u otro investigador científico quien quiera hacer investigaciones con Lophophora williamsii, tiene que cumplir con los (no triviales) requisitos reglamentarios aplicables. Este artículo presenta un examen de algunos de los esfuerzos prohibicionistas que allanaron el camino para las reglamentaciones actuales del peyote, acompañada por documentación del origen político-religioso de tales esfuerzos, los cuales involucraron la "aculturación" de los Americanos Nativos (es decir, la destrucción de las culturas de los Americanos Nativos). También le echamos una mirada a la aparición histórica de un esfuerzo organizado al nivel nacional y coordinado por misioneros y otros prohibicionistas, cuyo objetivo era convencer al Congreso de los EEUU de que debía promulgarse legislación anti-peyote, lo cual se manifestó repetidamente durante un periodo de más de 50 años, hasta que finalmente tuvieron éxito en la forma del Controlled Substances Act de 1970. En vista de los cambios en curso en el estado legal/regulador de Cannabis sp. (otra planta de la Lista l que fue objeto de ilegalidad durante el ascenso de los prohibicionistas al predominio político), comparamos y contrastamos las dos plantas con un ojo hacia el futuro especulativo del peyote.

KEY Words: Lophophora williamsii, peyote, religion, drug prohibition, American Indian culture, cannabis

\section{INTRODUCTION}

Peyote (Lophophora williamsii) is a small cactus of the Chihuahuan Desert and Tamaulipan Thornscrub regions of the Borderlands of Mexico and Texas (Fig. 1) that has a history of human use dating back at least 6,000 years (Terry et al. 2006). Currently its principal uses are medicinal sensu lato, including ceremonial use in meetings of the Native American Church (NAC), an organization which was founded in Oklahoma in 1918 (Stewart 1987) and which has subsequently spread to include congregations throughout the 50 states as well as Canada and Mexico (Terry, pers. obs.). Peyote is also part of the folk medicine tradition in the areas where it grows.

In the USA, the use of peyote by American Indians (or anyone else) was not widely known outside the tribal cultures-although aggressive official efforts were made to publicize and demonize it by one Bureau of Indian Affairs agent (Johnson 1912), in much the same manner as cannabis was later vigorously demonized by a single individual in the federal government in the 1930s and 1940s (Anslinger 1937; Anslinger \& Cooper 1937)_until the 1950s, when Aldous Huxley published The Doors of Perception (1954) and the Beat Genera- 


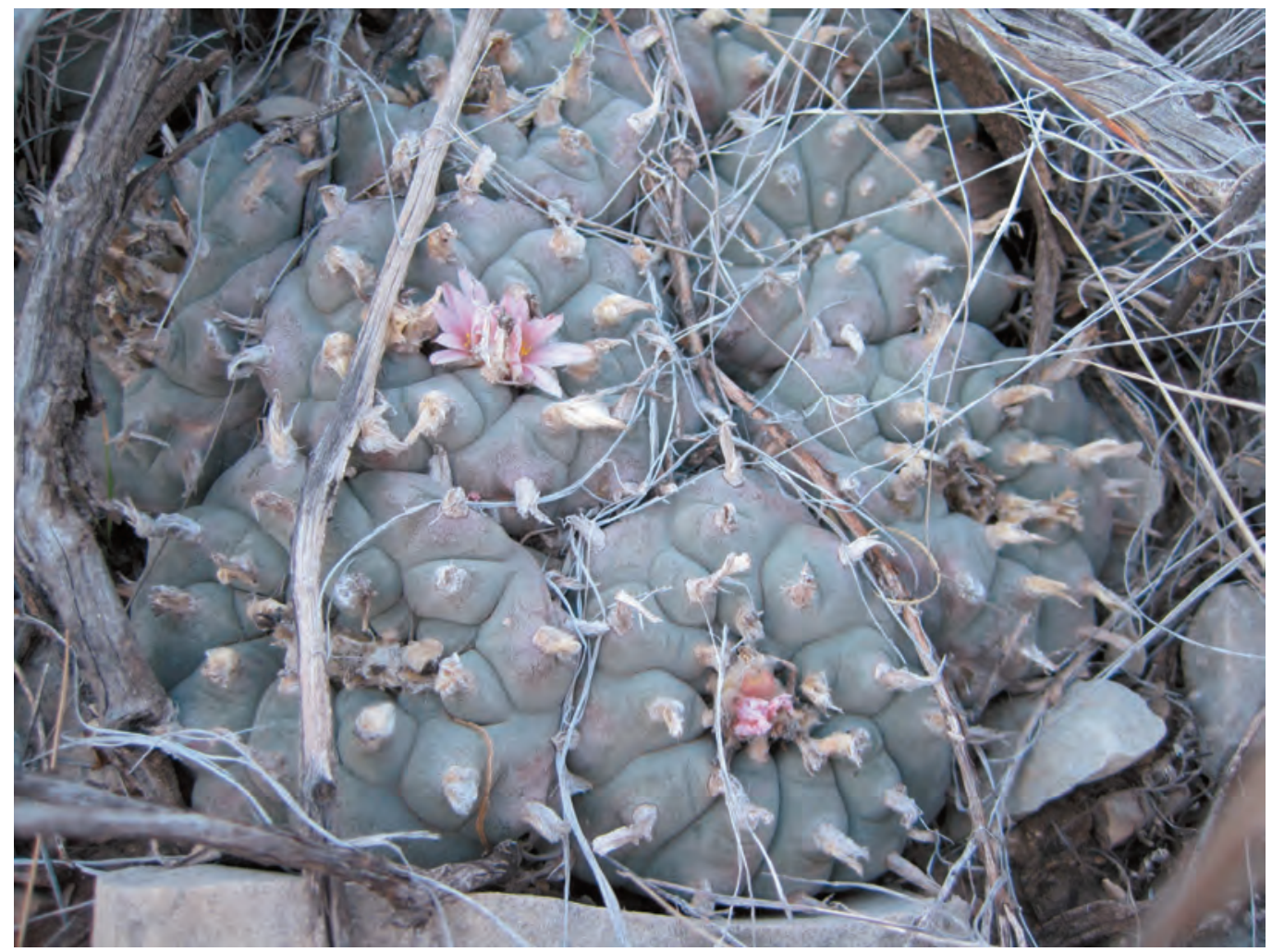

FIG. 1. A large, multi-stemmed peyote plant growing in the understory of the Chihuahuan Desert of West Texas.

tion discovered the psychoactive effects of peyote and its principal alkaloid, mescaline (e g, Kerouac 1955). As the Beatniks, who were always a small artistic and literary subculture constituting only a tiny fraction of the U.S. population, gradually faded from the scene due to actuarial attrition, they were replaced in the 1960s and 1970s by a new "counterculture" that included the Hippies—essentially a widespread and highly vocal generation of young people who espoused quite different values from those of the dominant culture with which they reluctantly shared the country. Among those values, clearly articulated in the pop music and literature of the time (e.g., Dylan 1966; Robbins 1971), was an often sophisticated taste for a spectrum of psychoactive drugs which the cognoscenti of the counterculture referred to as "psychedelics" (drugs that expand the mind) which, of course, included peyote.

As the 1960s progressed, several forces came to bear on peyote and its regulation:

(1) Drug use in general increased in the U.S., due in part to the counterculture's openness to experimentation with drugs for their psychoactive effects, a broader selection of both traditional and novel materials becoming available, and also due to the exposure to drugs (particularly cannabis and opiates) that occurred on a massive scale among U.S. soldiers in the war in Vietnam (Bentel \& Smith 1971).

(2) In addition to the "baseline" level of peyote harvesting by American Indians for their ceremonial use, in the 1960s the wild peyote populations were invaded by non-Indians of the counterculture, seeking peyote for their own uses, some of which could be objectively described as ceremonial, spiritual or educational, and some of which were described pejoratively as "recreational". This increased level of harvesting in the wild peyote populations in South Texas resulted in the gradual decimation of those populations, 
which even now remain the only legal source of peyote for NAC groups across the U.S. The increased harvesting — generally by trespassing — also created animosity between the uninvited harvesters and the ranchers on whose land the peyote grew. Another effect of increased harvesting of peyote from the limited-and shrinking - area of land in Texas where peyote grew in commercial quantities, was the gradual realization among many American Indians in the 1990s that peyote of the desired size and potency was in short supply. Indeed, by the first decade of the $21^{\text {st }}$ century, the sacramental quality of peyote had deteriorated markedly (Texas Department of Public Safety, unpublished data) as the licensed peyote distributors and their workers had no choice but to harvest the mostly small buttons that constituted the regrowth from previous (recent) harvests. The small, immature regrowth buttons with their markedly reduced mescaline content (Kalam et al. 2013) had largely replaced mature peyote plants in the accessible South Texas populations, and some Road Men (American Indian spiritual leaders who lead the NAC peyote meetings) were finding it difficult to obtain adequate supplies of peyote for their own groups of NAC members, and therefore they no longer had the luxury of being able to invite non-NAC members into their ceremonies (E. Jackson, personal communication). This consequence of the peyote shortage was compounded by an announcement by the U.S. Drug Enforcement Administration (DEA) of a possible narrowing of their definition of the subset of Native Americans who would be permitted to use peyote legally in their religious ceremonies_namely that only "members of federally recognized tribes" would benefit from the legislative exemption from prosecution for the use of peyote in their religious ceremonies (Nagel 2001, in litt.). This followed an earlier suggestion from DEA that anyone other than members of federally recognized tribes be banned from participation in peyote ceremonies; the Native American Church of North America (NACNA) formally voted to adopt this policy for their organization in June of 1993 (NACNA 1993). The result was the loss of a socioreligious meeting venue where trans-cultural understanding and harmony could be achieved between non-Indians and Native Americans, and also between members of federally recognized tribes and members of federally unrecognized tribes.

(3) Paranoia about alleged harmful effects of psychedelics, enhanced by ignorance about the pharmacology of psychedelics among the U.S. cultural mainstream and by the dire alarmist reports in newspapers and popular publications (examples with regard to peyote include Anonymous 1916; Seymour 1916; Tranter 1942; Davis 1961), affected the thinking of the ruling class/generation, particularly in the 1960s as the gap between the mainstream culture and the counterculture widened, due in part to differences in perception and experience of the psychedelics per se and in part to the increasing volume and stridency of U.S. domestic protests against the Vietnam War, particularly on the part of the younger generation.

(4) The Controlled Substances Act of 1970 (CSA) was the dominant culture's presumptive solution to "the Drug Problem". It had a number of flaws, however, and one of them was classifying peyote as a Schedule 1 Controlled Substance-defined as a substance for which "(A) the drug or other substance has a high potential for abuse; (B) the drug or other substance has no currently accepted medical use in treatment in the United States; and (C) there is a lack of accepted safety for use of the drug or other substance under medical supervision" (Drug Enforcement Administration 2015). That compound error by the U.S. Congress and the congressional advisors could be attributed to their lumping peyote with the "hallucinogens" without recognition for the legitimacy of its indigenous uses, amidst the hasty assembly of the CSA by the advisors of Congress, which was more interested in "solving the drug problem" with legislation that would appeal to the beliefs of their constituents than they were in discovering the facts (both pharmacological and cultural) about peyote. Peyote is a "hallucinogenic" plant, but it clearly possesses a long history of medicinal and ceremonial applications.

The clearest manifestation of the latter observation is the way Congress dealt with "the Native American problem" in framing the CSA and subsequent peyote legislation. The "inconvenient truth" was that the Native Americans—who were becoming increasingly vocal and politically powerful—had been using peyote legally in the U.S. ever since the NAC was established by charter in Oklahoma in 1918, and some tribes (e.g., the Co- 
manche and the Caddo) could point to their oral histories as evidence that their use of peyote for medical and spiritual purposes went back several centuries before that. Intense lobbying and propaganda to suppress this indigenous use of peyote had been made earlier in the $20^{\text {th }}$ century by prohibitionists and religious opponents to the peyote religion (e.g., Hall 1920; Haskell Institute 1917; Parker 1917; Sells 1920; Hayden in U.S. Congress 1921). The American Indians and their allies repeated their strong case to several Congresses over the years (including those of 1918, 1921, 1937 and 1963), persisting through the discussions leading up to the American Indian Religious Freedom Act Amendments of 1994 (AIRFAA), that their ceremonial (or "religious") use of peyote was protected by the First Amendment of the U.S. Constitution and should not therefore be subject to the prohibition of peyote use that was imposed in the Controlled Substances Act. The Native Americans were victorious in the end, and Congress included in AIRFAA an exemption for "the nondrug use of peyote in bona fide religious ceremonies of the [NAC]." And yet peyote (the plant) and mescaline (the predominant psychoactive alkaloid in the plant) remained in Schedule 1 - the same schedule that included LSD and heroin-indicating that peyote was still considered to be a "dangerous drug" under federal law. Carrying the logic one step further, the classification of peyote as a Schedule 1 drug, plus the AIRFAA language that explicitly provides an exemption allowing the continued use of peyote by American Indians, clearly signifies that Congress was claiming that peyote is a dangerous drug for most people but is perfectly safe and wholesome for American Indians-irrespective of whether their tribe or group had ever actually used peyote historically or not. What a fascinating toxicological anomaly!

Congress had, for reasons unfettered by facts, long viewed peyote as an addictive substance. This calls to mind Francis Bacon's observation: "Quod enim mavult homo verum esse, id potius credit." ["For man believes what he prefers to be true."] (Bacon 1620). Congress had long selectively respected the testimony coming from missionaries, other religiously motivated zealots, Indian agents and law enforcers over that presented by qualified scientists and unbiased health professionals. Clear provisions for committing those persons habituated to peyote to the federal Narcotic Farms were included in the original legislation creating those two facilities (U.S. Congress 1929). The Congressional presupposition of the blatantly false notion of peyote being addictive, was perfectly compatible with the CSA classification of peyote as Schedule 1 because of its alleged "high potential for abuse". An editorial in the March 15, 1916 Red Lake News captured both the degree of misinformation and misconceptions respected by Congress and the motivations underlying the war being waged against peyote and the peyote religion:

The physiological and toxic action of peyote places it in the same general class with opium, cocaine, Indian hemp and chloral hydrate. [...] This action, if repeated, unquestionably results in a fixed habit. The normal functions of the human body can not be interfered with at frequent intervals by such an agent as peyote without serious injury resulting. Even if the physiological effects of this drug were not serious, its use would have to be prohibited for the same sociological reasons as have led the Government strongly but tactfully to modify Indian dances. As is well known, exercises which the Indians consider of a religious nature are made the occasion of taking the drug. These meetings are held as often as once a week. [...] Furthermore, the effects of the drug in making the Indian contented with his present attainments seriously interfere with his progress by cuttink [sic] off from him the possibility of healthful aspiration. It is needless to say that peyote is a greater enemy to civilization, especially to the Indian race, than whiskey. (Anonymous newspaper editor 1916).

In the eyes of officials such as Anslinger, the provisions for peyote addicts in the legislation establishing the federal Narcotic Farms were regarded to mean that peyote was already considered to be an illegal and dangerous plant (Tranter 1942, citing Anslinger, personal communication). However, the claim that peyote is addictive has never been substantiated scientifically. On the contrary, it is universally recognized, both by members of the NAC and by experts in the modern medical community (e.g., H.G. Pope, personal communication), that peyote is not addictive, as can be evidenced by the fact that peyote ceremonies are never scheduled for several consecutive days; they are normally held at most once a week and, for many NAC groups, once a month or even 
less frequently (C.B. Hopkins, personal communication). Peyote ingestion by NAC members is normally limited to peyote ceremonies. Such low frequency of self-administration is clearly not compatible with the patterns of daily use typical of an addictive drug.

Regarding the question of whether any neurotoxicity or cognitive impairment is caused by the ceremonial use of peyote, the data from a study designed to address this question showed no evidence of either in NAC members using peyote ceremonially on a regular basis (Halpern et al. 2005).

In a study of hospital records of an urban population of what appear to be non-NAC members who sought medical attention after self-administration of peyote or mescaline, the authors concluded: "Most peyote intoxications appear to be mild in nature and are unlikely to produce life-threatening symptoms" (Carstairs \& Cantrell 2010). The most common clinical sign observed was tachycardia (to be expected from the structural similarity of the mescaline molecule to other sympathomimetic phenethylamines), and the most common clinical symptom noted in the study was "hallucinations" (undefined in the report). The proposition that the unknowing participants in the study were not NAC members, is supported by the fact that, to our knowledge, hallucinations are never reported by NAC participants in peyote ceremonies—only visions.

Classification in Schedule 1 also denotes that the drug in question "has no accepted medical use in the United States." The classification of peyote as Schedule 1 by the U.S. Congress in 1970 raises an important question: Who failed to accept the medical uses (plural!) of peyote over at least the last 500 years, and why? The very name of the peyote plant in several tribal languages is the same as the word for medicine. Even in modern American English, members of the Native American Church consistently use the word "medicine" to refer to peyote. There is a substantial literature on the therapeutic uses of peyote among the American Indian tribes (e.g., Schultes 1938, 1940). There are also clear descriptions of bona fide medical uses of peyote in the $16^{\text {th }}$ century Spanish literature (e.g., Hernández 1628 [1577]; Sahagun 1829 [1582]). At present there are widespread uses of peyote as topical tinctures, oils (aceites) and ointments (pomadas) in Mexico, and a number of these products are sold freely as over-the-counter remedies for rheumatic muscle pains (Fig. 2). It is clear that, contrary to the ample available evidence, the U.S. Congress and its advisors failed to recognize the medical value of peyote to ordinary people who live with and value the plant as a therapeutic agent, and the reason for that deliberate failure was that they needed to force peyote into Schedule 1 in order to maximize its "scare value" to the U.S. public, so that the citizens would feel amply protected from the dangers (falsely) attributed to peyote by our ill-informed legislators.

There currently appears to be little traction for post-hoc efforts to apply valid scientific data to the regulation of peyote, and so peyote remains relegated to Schedule 1 (Fig. 3). And let us be clear: the blame for assignment of peyote to Schedule 1 lies squarely on the shoulders of the U.S. Congress. That scheduling of peyote was done in the same legislative act (the CSA) that created the DEA. Once the CSA was enacted, it was incumbent upon the DEA to enforce it as best they could, despite the masses of contradictions-not merely bad science, but anti-science-that Congress enshrined in the legislation for the political purpose of satisfying their antidrug constituencies.

Almost all Schedule 1 drugs regulated under the CSA are chemical compounds that have politically unpopular pharmacological activity. There are two interesting exceptions to that generalization: peyote and cannabis. In both cases, not only the principal pharmacologically active constituents of the plants (mescaline in the case of peyote), but also the whole plants (living or dead), have been placed in Schedule 1 by Congress or the DEA. It has recently become obvious-and is becoming daily more obvious with the current proliferation of valid scientific studies of cannabis being published in respected scientific journals (Committee on the Health Effects of Marijuana 2017) — that cannabis was relegated to Schedule 1 in the CSA largely because it had been relentlessly demonized in false and blatantly racist propaganda by Harry Anslinger (Anslinger 1937; Anslinger \& Cooper 1937). The winds of change are blowing favorably for cannabis now, with the plant being decriminalized for medical use in over half the states of the United States and for "recreational" use in a smaller but growing number of states. However, at the federal level the plant remains both illegal and stuck in Schedule 1 in accordance with the CSA. Accordingly, contradiction and friction remain between state law and federal 


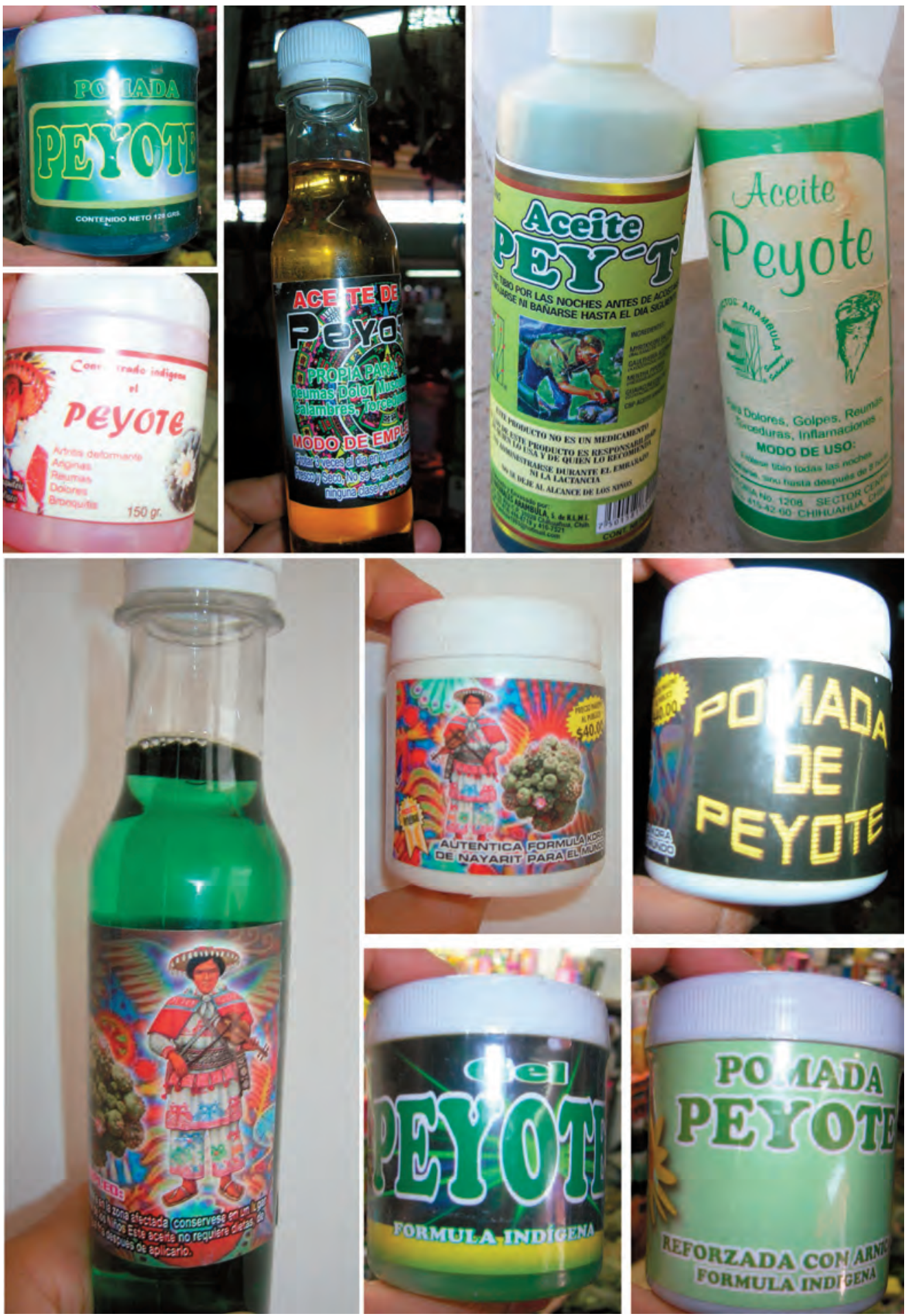

FIG. 2. A selection of topical pomadas (ointments) and aceites (oils) with labeling which suggests that peyote is a major active ingredient for the topical treatment of rheumatic pains. 


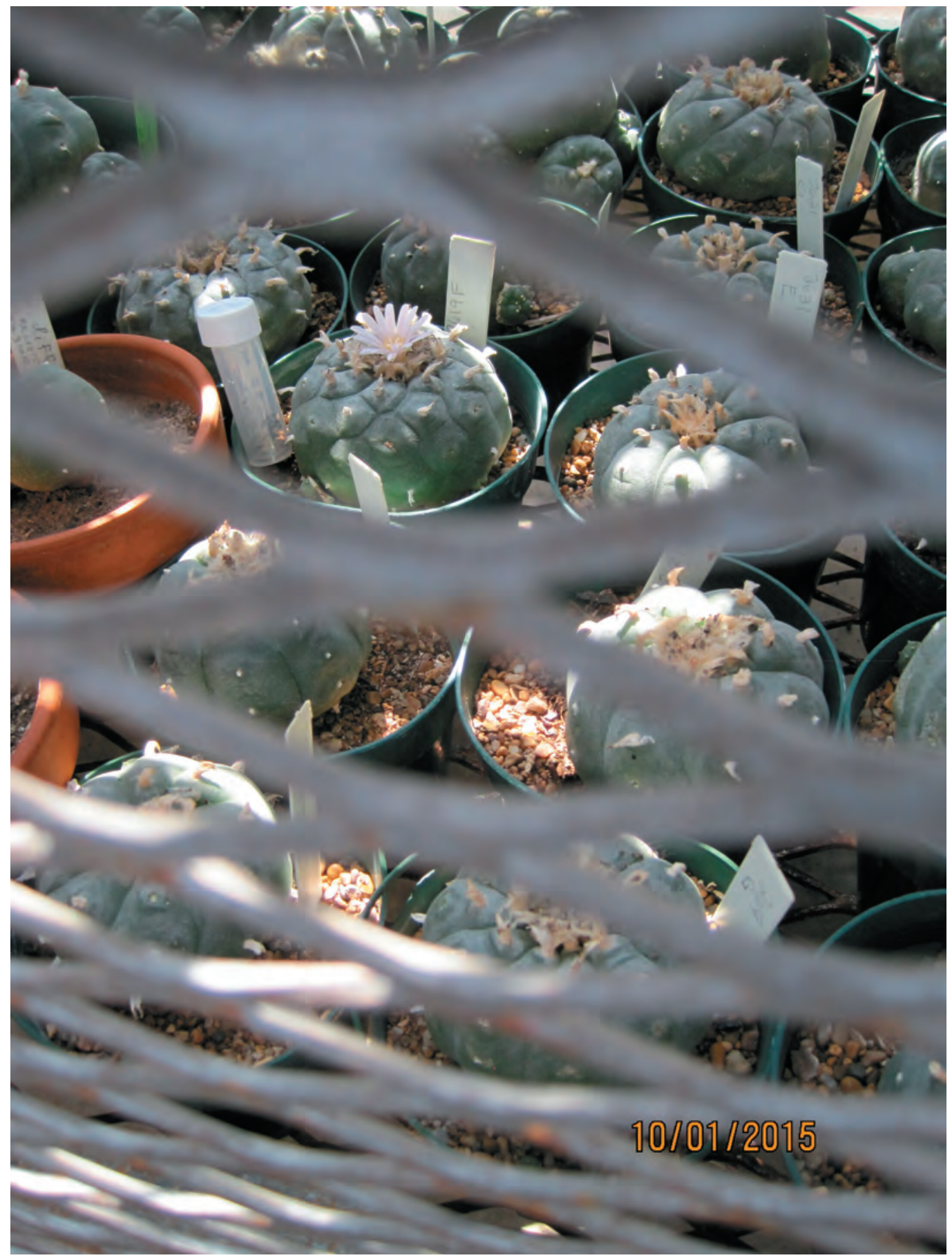

FIG. 3. Peyote in bloom behind bars. The purpose of the cage is to prevent "diversion" of the Schedule 1 plant. 
law on the regulation of cannabis. However, the notion that Congress may act to remove cannabis from Schedule 1 of the CSA in the foreseeable future is no longer laughable.

But where does that leave the other whole plant regulated by the CSA-peyote? While it is true that peyote, like cannabis, was politically packaged as a sheep in wolf's clothing in the 1960s, ensuring its classification in Schedule 1 of the CSA, reversing that original CSA classification would be a more difficult process for peyote than for cannabis. The principal reasons for this include:

(1) Cannabis is much better known than peyote in mainstream U.S. society and is far more widely used. Three U.S. Presidents have admitted to having smoked cannabis, and recent research indicates that 49\% of the U.S. population has done likewise, whereas only about $2 \%$ of Americans has ever ingested peyote (Krebs \& Johansen 2013). Cannabis occurs naturally in Asia, is naturalized in the U.S., and is widely cultivated on every continent except Antarctica, whereas peyote occurs naturally only in Mexico and the U.S., and is cultivated only on a very small scale, mostly for the ornamental cactus market in Europe and Asia. Accordingly, peyote is less well-known — and particularly less appreciated for its medicinal usesoutside of its range of natural occurrence in northeastern Mexico and adjacent Texas.

(2) The potential commercial peyote market is microscopic compared to the demonstrably enormous market for cannabis, and cannabis (a fast-growing massive annual) brings a return on investment that is far larger than what can be projected for peyote (a slow growing, small perennial, normally requiring about a decade between seed germination and appropriate first harvesting). Because of (1) and (2), funding for safety and efficacy studies of new medical uses of peyote is still scarce-in contrast to the scrambling of investors to provide funding for studies of new medical uses of cannabis and its assorted molecular constituents.

(3) Although the expensive and ineffectual "War on Drugs" is now waning, ignorance and fear still surround the group of drugs pejoratively characterized as "hallucinogens," and peyote is still considered by federal law to belong to that group of psychoactive drugs. It is actually possible to find drug treatment services offered for peyote addiction (e.g., Recovery.org 2015), though it seems doubtful that such organizations have encountered any calls for their services. Or at least there is no apparent evidence suggesting that anything has changed since 1945 when R.C. Williams, the assistant Secretary of State, responded to then Commissioner of Indian Affairs John Collier that they had never treated a peyote addict at the federal Narcotic Farm at Lexington, Kentucky (Williams 1945). In addition, knowledgeable authorities have maintained for decades that the term "hallucinogen" is inappropriate for peyote (which causes no hallucinations in the sense of seeing objects that are not present), and that the term "entheogen" is a more accurate characterization for a religious sacrament such as peyote (see Ruck et al. 1979).

In what little work has been published on medicinal uses of peyote (e g, Franco-Molina et al. 2003; Zuo et al. 2011), the results suggest that peyote has potential medicinal value that may support the anecdotal accounts. Similarly the persistence and proliferation of topical folk-pharmaceutical aceites and pomadas for the relief of rheumatic pain likewise suggest that there is a need for more research into the activity of peyote as medicine.

How long it will take peyote to shake off the chains of misconception associated with the War on Drugs is unclear. However, it is not unreasonable to expect that the unavoidable shift in public opinion eventually following the ongoing legislative reform of the regulation of cannabis will someday clear the political path for peyote to be more widely investigated for medicinal benefits, to be more widely accepted, and to take its rightful place as medicine, in the pharmacopoeia as well as in the tipi.

\section{ACKNOWLEDGMENTS}

We are very appreciative of the efforts of the two reviewers, whose input resulted in substantial improvement in the focus and clarity of the paper. We wish to thank the Alvin A. and Roberta T. Klein Foundation for generous support of the cactus work in our lab. 
REFERENCES

Anonymous. 1916. Red Lake News (Red Lake, Minnesota), 15 March, page 2. Editorial column. (Quote contained in that article was drawn from the Annual Report of the Commissioner for Indian Affairs, 1911).

Anonymous. 1916. The peyote evil. The Steamboat Pilot (July 5). P. 2.

ANSLINGER, H.J. 1937. Hearing on the Marihuana Tax Act of 1937, Statement of H.J. Anslinger (http://www.druglibrary.org/ schaffer/hemp/taxact/t10a.htm) \& Additional statement of H.J. Anslinger , Commissioner of Narcotics (http://www. druglibrary.org/schaffer/hemp/taxact/anslng1.htm.)

AnsLinger, H.J. \& C.R. Cooper. 1937. Marijuana: Assassin of youth. Amer. Mag. 124:19-20, 150-153.

BACON, F. 1620. Aphorism 49. Novum Organum, Book 1. Joannum Billium Typographum Regium, London, U.K.

BENTEL, D.J. \& D.E. SMITH 1971. Drug abuse in combat: The crisis of drugs and addiction among American troops in Vietnam. J. Psychedelic Drugs 4(1):23-30.

CARstaiRs, S.D. \& F.L. Cantrell. 2010. Peyote and mescaline exposures: A 12-year review of a statewide poison center database. Clin. Toxicol. 48:350-353.

Committee on the Health Effects of Marijuana. 2017. The health effects of Cannabis and cannabinoids: The current state of evidence and recommendations for research. National Academies of Sciences, Engineering, and Medicine. (PDF is available at http://www.nap.edu/24625.)

DAvis, J.H. 1961. Peyote: America's baffling sex button. Escape to Adventure (May) 14-15, 60, 62-64.

Drug Enforcement Administration, 2015. DEA drug info, drug scheduling. www.dea.gov/druginfo/ds.shtml, accessed 18 September 2015. [or www.deadiversion.usdoj.gov/21cfr/21 usc/812.htm][2/27/17]

DyLAN, B. 1973. Dylan, Bob. Writings and drawings. Alfred A. Knopf, New York, U.S.A. Pp. 205, 212-213.

Franco-Molina, M., R. Gomez-Flores, P. Tamez-Guerra, R. Tamez-Guerra, L. Castillo-Leon, \& C. Rodriguez-Padilla. 2003. In vitro immunopotentiating properties and tumour cell toxicity induced by Lophophora williamsii (peyote cactus) methanolic extract. Phytotherapy Res. 17(9):1076-1081.

HALL, R.D. 1920. Peyote. Home Mission Monthly 34(4):89.

Halpern, J.H., A.R. Sherwood, J.I. Hudson, D. Yurgelun-Todd, \& H.G. Pope JR. 2005. Psychological and cognitive effects of longterm peyote use among Native Americans. Biol. Psychiatry 58:624-631.

Haskell Institute. 1917. Peyote. The Indian Leader 21(13):18-19.

HERnÁNDEZ, F. 1628 [1577]. Rerum medicarum Novae Hispaniae thesaurus, sue (nova) plantarum, animalium, mineralium Mexicanorum historia. Mascardi, Rome, Italy.

HuxLEY, A. 1954. The doors of perception. Chatto \& Windus, London, U.K.

JoHnson, W.E. 1912. History, use and effects of peyote. Indian School J. 12:239-242, 289-293.

Kalam, M.A., M.T. Klein, D. Hulsey, K. Trout, P. Daley, \& M. Terry 2013. A preliminary report of mescaline concentrations in small regrowth crowns vs. mature crowns of Lophophora williamsii (Cactaceae): Cultural, economic and conservation implications. J. Bot. Res. Inst. Texas 7(1):435-440.

KeRouAC, J. 1957. On the road. Viking Press, New York, NY, U.S.A.

KreBs, T.S. \& P.- Ø. Johansen. 2013. Over 30 million psychedelic users in the United States. F1000Research 2:98. doi: 10.12688/f1000research.2-98.v1.

NACNA 1993. Resolution 6-19-93A regarding Title II of DEA S. 1021 "Traditional use of peyote." 44th Annual Conference of the Native American Church of North America, 18-20 June, New Town, North Dakota, U.S.A.

NAGEL, L.M. 2001. Proposed changes in DEA's peyote regulation. In litt., 18 Dec 2001.

PARKER, A.C. 1917. The perils of peyote. Amer. Indian Mag. 5(1):12-13.

RECOVERY.ORG. http://www.recovery.org/topics/choosing-the-best-inpatient-peyote-recovery-center/ Accessed online 19 September 2015.

RobBins, T. 1971. Another Roadside Attraction. Random House, New York, U.S.A.

Ruck, C.A.P., J. Bigwood, D. StAPles, J. Ott, \& R.G. WAsson. 1979. Entheogens. J. Psychedelic Drugs 11(1-2):145-146.

SCHULtes, R.E. 1938. The appeal of peyote (Lophophora Williamsii) as a medicine. Amer. Anthropol. 40:698-715.

SCHULtes, R.E. 1940. The aboriginal therapeutic uses of Lophophora Williamsii. Cactus Succ. J. 12:177-181.

Sahagun, B. DE. 1829 [1582]. Historia General de las Cosas de Nueva España. Carlos Maria de Bustamante, Mexico City, Mexico.

Sells, C. 1920. Peyote. Annual Report of the Commissioner of Indian Affairs. Government Printing Office, Washington, D.C., U.S.A. P. 20.

SeYmour, G. 1916. Peyote worship: An Indian cult and a powerful drug. The Red Man 8(10):341-351. 
Stewart, O.C. 1987. Peyote religion: A history. University of Oklahoma Press, Norman, U.S.A.

Terry, M., K.L. Steelman, T. Guilderson, P. Dering, \& M.W. Rowe. 2006. Lower Pecos and Coahuila peyote: New radiocarbon dates. J. Archaeol. Sci. 33:1017-1021.

Tranter, C.L. 1942. Peyote: New dope menace. PIC Magazine. Street \& Smith, New York, U.S.A. Pp. 6-9.

U.S. CongRESS. 1918. Bill for prohibition of use of peyote. H.R. 2614. 65th Congress. Report 560.

U.S. Congress. 1921. House debate on peyote legislation. Congressional Record, 4681-4691. [Comments and letters submitted by Representative Carl Hayden are on pages 4681-4682.]

U.S. CongreSS. 1929. Porter Narcotic Farm Act (P.L. 70-672, 45 Stat. 1085) [See chapter 82.]

U.S. Congress. 1937. Documents on Peyote. Part 1. US Senate SB-1399.

U.S. Congress. 1963. Constitutional Rights of the American Indian. Hearings before the Senate Subcommittee on Constitutional Rights of the American Indian.

U.S. Congress. 1970. Controlled Substances Act (CSA). (P.L. 91-513, 84 Stat. 1242).

U.S. Congress. 1994. American Indian Religious Freedom Act, as Amended. (P.L. 103-344) [H.R. 4230].

WilLiAmS, R.C. 1945. Letter to John Collier. (Retrieved from the Shulgin Archives, Lafayette, California, U.S.A.)

Zuo, Z.-ү., X.-т. Song, ZHANG, X.-І., SH, \& B.-к. ZHou. 2011. Inhibitory and apoptosis-inducing effects of Lophophora williamsii extracts on HeLa cells. J. Med. PI. Res. 5(8):1305-1312. 